\title{
The Use of Technology in Corporate Management and Reporting of Climate-Related Risks
}

\section{Andrea Miglionico ${ }^{1}$}

Accepted: 13 December 2021 / Published online: 24 January 2022

(C) The Author(s) 2022

\begin{abstract}
Sustainable finance and climate change have emerged as areas of renewed interest in the wake of the global financial crisis, when the assessment of companies' risk management was shown to be the key to the prevention of systemic disruption. While many aspects of corporate disclosures were radically and quickly revised following the crisis, even several years later commentators have pointed to a continuing pressure for improvement to regulatory requirements in relation to financial statements. Much of the debate focuses on the need for expedited operational execution of reporting information. Over the past decade significant advances have taken place in digital technologies, especially with respect to the security and processing of granular data. This article examines how these new technologies can be deployed in a manner that will address the need to eliminate the vulnerabilities of the climate risk management process, which requires standardisation of data in order to improve managerial decision-making and the desired outcomes. It further explores the use of technology to enhance the evaluation of climate change impact on company exposures, and to advance transparency in regulatory reporting for financial institutions. Technology applications such as automated language systems offer opportunities to align corporate disclosure with climate change policy objectives, which in turn can increase sustainability in the performance of companies' activities.
\end{abstract}

Keywords Climate risk - Corporate disclosure $\cdot$ Regulatory reporting $\cdot$ Automated language systems $\cdot$ Standardisation of data $\cdot$ Climate litigation

\section{Introduction}

The use of technology to coordinate corporate governance mechanisms (e.g., board structures) has become attractive for monitoring compliance with climate change policies. Digital technologies offer opportunities to automate complex and manual

Andrea Miglionico

a.miglionico@reading.ac.uk

1 Lecturer, School of Law, University of Reading, Reading, UK 
investment analysis, the key challenge of sustainable decision-making. The Financial Stability Board (FSB) has launched a Task Force to mandate companies to incorporate information about the potential impact of climate change in their risk management process. ${ }^{1}$ This regulatory initiative has been complemented by the European Commission's Guidelines on Reporting Climate-related Information which aim to support corporations in managing sustainable reporting in financial statements. ${ }^{2}$ The FSB's Task Force together with the Commission's Guidelines marked a step forward in the transparency and accountability of corporations, although they did bring to light a gap in data sharing which makes it difficult to succeed in having quantitative information about climate risks. Companies lack adequate methodologies and clear indicators for the assessment of environmental issues: the absence of an international consensus on green investments creates information imbalances that limit the effectiveness of monitoring systems.

This article examines the use of digital technologies, specifically standardised representation of climate risk granular data, to aid the achievement of sustainable objectives in corporate disclosure. It discusses how automated language systems such as Natural Language Processing (NLP) can be deployed to improve the measurement of granular data and the provision of meaningful information. It then considers whether the application of NLP methods can promote effective compliance processes, while ensuring standardisation of data together with contractual certainty and predictability of enforcement actions in order to avoid losses on the part of companies. Climate risk disclosures can be expedited through modern technologies, which, in turn, can enhance the transparency of reporting outcomes. Information providers continue to improve quality and availability, although data continues to be one of the largest impediments to climate risk assessment. Technology offers the possibility of 'algorithmic' regulation by substantially automating financial reporting, which means that the real-time calculation of future exposure based on data and simulation of risk factors is now feasible in order to detect environment-related events. $^{3}$

The article proceeds as follows. Section 2 outlines the regulatory responses to climate change and sustainability: a copious set of recommendations have been published in the international arena with the aim of equipping companies with adequate tools for mitigating the implications of environmental externalities for financial activities. $^{4}$ The pressure of global regulators has encouraged firms to reduce the scarcity of climate information and ensure consistency in reporting requirements.

\footnotetext{
1 Financial Stability Board (2020), pp 49-50. The Task Force provides a classification of climate risks into physical risks and transition risks. Transition risks arise from the transition to a low-carbon and climate-resilient economy and affect the value creation and reputation of the company. Physical risks arise from the adverse effects of climate change, such as material events that cause disruptions and financial damages. Those risks are sources of financial losses and lead to exposure to credit default.

2 European Commission (2019).

3 Ryan-Collins (2019).

${ }^{4}$ United Nations Framework Convention on Climate Change (2015). https://unfccc.int/process-andmeetings/the-paris-agreement/the-paris-agreement (accessed 25 May 2021).
} 
Several initiatives focus on the possibility of establishing green finance objectives in sustainability reports, which represents a challenge for climate economic policies.

Section 3 examines the rationales for companies managing their climate risk and impact. It discusses the use of technology both in the disclosure of firms' activities with regard to climate and in the evaluation of the risks that climate change imposes on the firm. This Section also explores whether automation of climate disclosures is 'algorithm ready' and presented in a way that allows automated software-based compliance. It further argues that the application of technological solutions in climate data analysis may not be sufficiently complete to fulfil the reporting requirements. As a result, climate change litigation represents a significant indicator which enables companies' behaviour to be analysed and the risks of harmful environmental events to be audited.

Section 4 addresses how companies manage their climate risk, which involves an analysis of the achievements and potential downsides of algorithmic systems for processing granular climate information. Technology can improve information sharing and access to large volumes of climate data, which will allow firms to obtain a more insightful view of sustainable activities. ${ }^{5}$ The broader challenge is standardisation. Data should be held in consistent formats, or at least should be translatable into consistent formats, across all institutions. Standardisation will include a variety of granular data: agreement and support by regulators for standardised representations of contracts will support greater efficiencies in many aspects of regulatory reporting and oversight. ${ }^{6}$

The last Section sets out conclusive remarks and summarises the discussion about the potential of using new technologies to achieve desired regulatory outcomes in climate change financial risk disclosure.

\section{The Regulatory Landscape of Climate Change}

Tackling the impact of climate risk in order to preserve financial stability has become the main priority on the agenda of global regulators and national supervisory authorities. The Task Force on Climate-related Financial Disclosures (TCFD) formed by the FSB provides guidance to companies for the reporting of climate change implications for investment decisions. ${ }^{7}$ The TCFD aims to standardise climate change reporting requirements by providing a set of voluntary recommendations to be incorporated in companies' business models and the regulatory monitoring process. These reporting standards mark a shift towards a common framework of climate change disclosures. Specifically, it is recommended to disclose the models and data used to assess and manage relevant climate risks so as to make it easier for participants to acquire information about the potential vulnerabilities of a given company's management and oversight by the board.

\footnotetext{
5 Macchiavello and Siri (2021), pp 23-25.

6 Gal and Rubinfeld (2019), pp 752-753.

7 Financial Stability Board (2016), pp 10-11.
} 
In the UK, the Financial Conduct Authority (FCA) has proposed introducing binding rules requiring premium listed companies to disclose climate change financial risks in line with the TCFD. ${ }^{8}$ In a similar vein to the FCA's policy goals, HM Treasury ${ }^{9}$ and the Financial Reporting Council $^{10}$ have promoted mandatory best practices to implement TCFD disclosure obligations for UK corporations with the objective of addressing the lack of information about the financial impact of climate change. The UK Government has launched a consultation to require mandatory TCFD-aligned climate-related financial disclosures from publicly quoted companies, large private companies, and Limited Liability Partnerships. ${ }^{11}$ This consultation aims to develop the programme set in the 'Green Finance Strategy'" and to mandate listed firms to commit themselves to sustainable managerial actions. Further improvements in climate change regulation are recorded at EU level, where the Commission adopted the Action Plan on Financing Sustainable Growth, which was followed by the Taxonomy Regulation, ${ }^{13}$ an innovative piece of legislation which provides for harmonisation of the climate and energy targets set in the UN 2030 Agenda and the Paris Agreement. ${ }^{14}$

The Taxonomy Regulation adopts a binary approach (i.e., an activity is considered either compliant or not) and requires credit institutions and investment firms to comply with the reporting requirements for environmentally sustainable activities according to the non-financial disclosure (NFRD) obligations. ${ }^{15}$ The NFRD introduced mandatory rules for companies to incorporate non-financial statements in their annual reports in relation to the corporate social responsibility and environmental, social and governance (ESG) criteria. ${ }^{16}$ These reforms represent a step forward in the development of a mandatory reporting framework, although the measures face challenges on account of the scant incentives to establish sustainable corporate business strategies. Despite the evident progress in designing a sustainability agenda in the EU regulatory landscape, the successful achievement of a sufficient degree of harmonisation needs a significant change in the corporate governance model, which, in parallel, will require a level playing field of climate change rules.

\footnotetext{
${ }^{8}$ FCA (2021). See also FCA (2020).

9 HM Treasury (2020).

${ }^{10}$ Financial Reporting Council (2020), pp 6-7.

11 UK Department for Business, Energy \& Industrial Strategy (2021).

12 HM Treasury (2019).

13 EU Regulation No 2020/852 (Taxonomy) on the establishment of a framework to facilitate sustainable investment (OJ L 198/2020), p 13.

14 European Commission (2018).

15 EU Taxonomy Regulation (2020), Art. 8.

16 Directive 2014/95/EU of the European Parliament and of the Council of 22 October 2014 amending Directive 2013/34/EU as regards disclosure of non-financial and diversity information by certain large undertakings and groups (OJ L 330/2014), p 1.
} 


\section{Automation of the Climate Risk Assessment Process}

The use of technology in the corporate sector generally refers to algorithms in business decision-making, both in investment contracts and in business strategy. ${ }^{17}$ Automated mechanisms have the potential to assist with the governance of internal controls which are relevant for minimising reputational risk, legal risk and operational risk for companies. ${ }^{18}$ Automation of the climate risk assessment process can improve the accuracy and comparability of information, which would also enhance the ability of senior management to monitor report disclosures. In this context, the algorithmic climate risk assessment can advance the collection and classification of data in order to facilitate decision-making procedures.

Sophisticated algorithms trained to analyse legal rules can help businesses gather, process and analyse granular operational information relevant to the compliance with mandatory reporting requirements. By employing digital solutions, such as a distributed shared ledger, a company can more rapidly assess the potential harms of climate change and adverse sustainability impacts. Automated practices can support corporate compliance processes through the use of natural language processing and cognitive computing. However, as Armour et al. have observed, 'automated systems must be designed, customized, set up, maintained, and overseen', ${ }^{19}$ which requires human capital. The below demonstrates how these systems work, but the article is mindful that human engagement and supervision remain necessary in order to manage systemic biases or failures in algorithmic systems. ${ }^{20}$

Machine-learning programmes such as Natural Language Generation and NLP can be used to automate regulatory reports and detect environmental externalities. ${ }^{21}$ These artificial systems are classified as deep-learning applications which rely on neural networks to predict climate risk. ${ }^{22}$ NLP can extract regulations and decipher regulatory and control requirements (i.e., legislation 'gap' analysis tools) ${ }^{23}$ It is a computation tool designed to optimise prediction and classification tasks: the NLP system resembles the structure of the brain with the purpose of elaborating an objective function, e.g., the best combination between inputs and outputs. ${ }^{24}$ Using NLP-based systems, firms can improve operational and organisational awareness of information, as unstructured text can be swiftly converted into a formal representation which computers can interpret: this methodology can address the data challenges and increase climate risk detection and management accuracy. ${ }^{25}$ NLP techniques involve predictive approaches for identifying climate losses in corporate

\footnotetext{
17 Yeung (2019), pp 24-25.

18 Lui and Lamb (2018), pp 268-269.

19 Armour et al. (2020), p 14.

20 Johnson et al. (2019), p 511.

21 NLP is an application of AI that helps computers understand and interpret human language. Luccioni and Palacios (2019).

22 Gensler and Bailey (2020), p 2.

23 Gotthardt et al. (2020), pp 92-93.

24 Gensler and Bailey (2020), p 9.

25 Stein (2020), pp 899-900.
} 
disclosures and for analysing climate information: the categorised sections of the reports addressing specific climate risk serve to create accessible datasets for advancing compliance with regulatory requirements. Specifically, NLP tools help to understand what type of information should be disclosed, in what manner, with what frequency, and the extent to which the data needs to be verified. This can improve board management oversight and avoid confusion in classifying the categories of climate exposures. It is a valuable approach to detect potential climate-related disclosures and solve the ambiguity of textual information (e.g., different meanings of climate taxonomy) identified in corporate reports. Language-based algorithms can reduce uncertainties in the available metrics and increase comparability between score estimates: this can improve the standardisation of granular data in climate risk disclosure which is a major source of divergences. ${ }^{26}$

Corporations have started to produce reporting information in machine-readable form so that granular data processing can be expedited. ${ }^{27}$ Regulatory requirements (financial statements and periodic filings) are also adapted to machine readership, so that detection for regulatory non-compliance is also automated to an extent. This results in a strong relationship with AI applications, which influences managers' decision-making and affects desired outcomes. ${ }^{28}$ The use of algorithms and machine learning has become important at the level of corporate governance in facilitating corporate decision-making as well as improving corporate compliance such as with mandatory disclosure. In the banking sector, algorithmic systems for climate information processing can also assist with banks' prudential assessments and regulatory compliance: technological solutions to calculate risk weights have the potential to make transparent the metrics and targets applied in the internal models for climate risk. $^{29}$

The automated processing of granular climate-related data at firm level also assists with the valuation of all of a firm's assets, liabilities and off-balance-sheet commitments, possibly near real time. Improved standardisation would then help to facilitate the climate risk assessment process for firms and their investors, who could have access to transparent data to which to apply their own risk modelling and valuation techniques.

\subsection{Technology and the Disclosure of Firms' Activities That Impact the Climate}

There is growing concern about the implications of environmental risks in companies' business models, which show limitations in establishing a governance framework designed to ensure compliance with climate reporting. ${ }^{30}$ Corporations are in need of expedited organisational systems and effective measurement of climate

\footnotetext{
${ }^{26}$ Hain et al. (2021), pp 7-8.

27 Lewis and Young (2019), pp 587-589.

28 Björkegren et al. (2020).

29 Broeders and Schlooz (2021), pp 126-127.

30 Ferrarini (2020).
} 
data $^{31}$ in order to consider non-financial information in their business strategy. The shift towards sustainability reporting is the new frontier of companies' performance as well as regulatory compliance. It is commonly considered that financial reporting reflects a backward-looking and judgment-based approach to information, which raises concerns as regards the achievement of long-term sustainability goals. ${ }^{32}$ A key area of climate disclosure that needs improvements and consistency is strategic resilience in companies' business strategies. ${ }^{33}$ Considerable attention is being paid to enhancing this part of disclosure owing to lack of consolidation of global regulatory standards.

Technological advancements in the disclosure of firms' activities that impact the climate can be deployed to improve data standardisation and granularity of climate information. The use of technology to gather data can help companies demonstrate that their activities are sustainable for the environment and society. For instance, software applications (e.g., data mining and machine learning) can assist the management board to extract valuable information from climate data and identify which section of the annual report needs to account for environmental risks. ${ }^{34}$ This can also reduce firms' opportunistic behaviour to disclose climate information selectively. There is a prevalent sentiment among policy makers and shareholders on the need to introduce mandatory sustainability reporting for financial organisations. It is observed that disclosure of climate risk is a significant factor for investors and directors in their strategic management as they prefer standardised and mandatory obligations with regard to climate reporting. ${ }^{35}$ Ioannou and Serafeim have analysed the extent to which mandatory sustainability disclosure regulations have an impact on corporate disclosure practices, as it is unclear whether the ESG metrics would improve the transparency of firms. ${ }^{36}$ Integrating sustainability reporting in managerial decision-making entails the costs of gathering ESG information from professional data providers and the costs of changing organisational processes.

The European Commission study on directors' duties and sustainable corporate governance observed that 'companies lack a strategic perspective over sustainability and current practices fail to effectively identify and manage relevant sustainability risks and impacts'. ${ }^{37}$ Specifically, it is reported that corporate decision-making and board management do not adequately promote sustainable goals within the governance framework. The Commission emphasises the need to improve companies' social performance through legislation on directors' duties and sustainability under EU company law. ${ }^{38}$ This should enhance the sustainable values of corporate governance and foster sustainable corporate practices. However, efforts to mitigate the

\footnotetext{
31 Johnston (2018), p 29.

32 Lusk (2021), pp 7-8.

33 Sustainability Accounting Standards Board (2021), p 5.

34 Balch (2021).

35 Bresnahan et al. (2021), pp 13-15.

36 Ioannou and Serafeim (2019), pp 452-453.

37 European Commission (2020), p 42.

38 Ferrarini et al. (2021), pp 16-17.
} 
implications of climate change for financial institutions and interventions to foster organisational changes seem a déjà vu in the regulatory policy options.

National regulations do not establish mandatory obligations for companies to adopt and disclose sustainable objectives, which makes it difficult to align the corporate disclosure regime with climate reporting. ${ }^{39}$ The various guidelines on climate risks issued by the global regulators add layers of complexity and do not clarify the sustainability requirements to be incorporated in financial reporting. This voluntary set of soft law measures have created more uncertainty for shareholders and investors with the result that the perimeter of climate disclosures is left undefined.

The EU legislation standardises the sustainability impact under the principle of 'double materiality', which calculates sustainable outcomes (social and environmental values), but it does not indicate the sustainability metrics for measuring the impact of sustainable activities in corporate governance. Chiu argues that the metrics on sustainable impact constitute an essential indicator for evaluating the sustainability risks in a corporate's decision-making on investment. ${ }^{40}$ The regulation on sustainable disclosure requirements identifies the environmental and social objectives as a benchmark indicator for periodic financial reports. ${ }^{41}$ The Sustainable Finance Disclosure Regulation adopts a 'comply or explain' approach to promote harmonisation of climate disclosure standards, although it does not address the issues of limited availability of ESG data and the lack of a central supervisor. ${ }^{42}$ Another concern is the absence of a degree of liability with respect to market participants and financial institutions for breach of the sustainability disclosure rules and management (i.e., oversight) duties. It can be argued that investors' desire for social responsibility on the part of companies seems constrained by the undefined materiality of climate change impact on corporate disclosures.

The identification and quantification of the material factors of climate change are inherently dependent on publicly available information, which offers little evidence of direct physical and non-physical effects on business activities. ${ }^{43}$ The question is: to what extent do corporations have to indicate the amount of materiality which is necessary for inclusion in the financial report? Corporations would not have particular incentives to disclose items of information which involve negative exposure to investors and shareholders: it is likely that they would avoid analyses of materiality parameters because of the high costs of accessing this information. In the absence of mandatory disclosure obligations, financial firms have an appetite to limit the volume of reporting in order to reduce the burdensome procedures of internal control systems. Further, corporations are not required to update their measurement methodologies, making the assessment process particularly vulnerable when it comes to capturing climate risks. The classification of material climate risk drivers and their

\footnotetext{
39 Schoenefeld et al. (2018), pp 121-122.

40 Chiu (2021).

41 For a commentary, see Gortsos (2020).

42 EU Regulation 2019/2088 on sustainability-related disclosures in the financial services sector (OJ L 317/2019), p 1; see Busch (2021).

43 Burton (2010), p 1296.
} 
concentration in financial activities depends on the availability of relevant data, which affects the management decision to disclose hazard events.

\subsection{Automated Models of Climate Risk Management for Firms}

The rapid transition to environmental policies is challenging the paradigm of companies' business models as regards the way to assess the level of exposure to climate risk factors. ${ }^{44}$ Accurate estimation of climate exposures lowers the costs of tracking pollution emissions and contributes to the mitigation of endogenous financial shocks arising from environmental damages. Although ESG criteria are being refined by industry and rating providers, firms are in need of integrating key and accepted parameters into their business strategies. ${ }^{45}$ By modelling well-accepted ESG criteria into corporate climate risk data and management systems, companies can be assisted in re-orienting their internal operational systems. This may even have an impact upon the nature of corporate governance, corporate purpose and business model. Stakeholder engagement can be improved too. ${ }^{46}$ Corporate decision-making can be informed by forward-looking predictions as to the climate impact on corporate governance. ${ }^{47}$ Möslein and Engsig argue that certification schemes provide a means for sustainable corporations to signal their good behaviour to the market with the aim of promoting a sustainable corporate governance framework. ${ }^{48}$

Evaluating financial risks associated with climate change involves the application of technological solutions that have the potential to improve the quality of information by translating granular metrics into accurate predictions. Avgouleas points out that 'spatial finance can offer a valuable measure of the impact of sustainable investments' through the use of machine-learning technology for climate change evaluation. ${ }^{49}$ The digitalisation of the corporate sector has been faced with an increasing use of automated processes, e.g., machine learning, neural networks and adaptive algorithms that display intelligent behaviour by taking actions to advance process innovation. ${ }^{50}$ The deployment of technology has resulted in the automation of firms' operating systems by supporting both risk assessment and peer comparison. Machine learning software can assist manual intervention, although automatic procedures rely on algorithms which, if the software is not perfectly designed, can lead to problems. ${ }^{51}$ Making climate data machine readable entails accurate control and permissioning for access to and screening of data: artificial intelligence (AI) and cognitive computing can enhance real-time information and provide evidence about

\footnotetext{
44 Carney (2015), pp 5-6.

45 Inderst et al. (2012), p 13.

46 Lund and Pollman (2021), pp 47-48.

47 Zenghelis and Stern (2016).

48 Möslein and Engsig Sørensen (2021), pp 8-9.

49 Avgouleas (2021), p 57 [emphasis added].

50 Enriques and Zetzsche (2020), pp 59-60.

51 Chiu and Lim (2021), pp 13-15.
} 
the climate impact on financial assets. ${ }^{52}$ However, the lack of available data on companies' exposure to environmental hazards (e.g., natural disasters, weather disruptions, concentration of greenhouse gases) constitutes a barrier for companies and their investors alike who find it difficult to evaluate companies' strategies towards climate change issues.

A key challenge for corporations is to identify a suitable modelling approach for each company's needs in assessing the material factors of climate change relevant to them. Different models have been proposed among regulators focused on estimating foreseeable transition costs and losses, such as by adopting scenario analysis, sensitivity analysis and stress tests. ${ }^{53}$ Although these models still require refinement, such as in relation to data gaps, ${ }^{54}$ more sophisticated stress-testing and scenario analysis approaches for corporate climate risk management are emerging. Eley proposes transition capacity testing as an alternative model for the classification of the exposures that are most vulnerable to climate change. ${ }^{55}$ These methodologies incorporate forward-looking information complemented by historical data and provide an assessment of the varying degrees of environmental risk. However, the main question relates to the credibility and reliability of such approaches, given the fact that they are essentially based on market information and the backward-looking materiality of risk, which do not guarantee accurate long-term forecasts. ${ }^{56}$ Climate risk modelling and stress-testing processes can support increased processing of granular information in order to achieve the required precision and to support swifter corporate decision-making to address the effects of environmental adversities.

\subsection{Climate Litigation as a New Taxonomy of Corporate Exposures}

One area of climate risk management crucial for corporations is climate risk litigation management. The increasing attention paid to climate cases filed against corporations has given rise to considerable debate about enforcing 'brown activities' (carbon emissions mainly dependent on fossil fuels) and addressing non-sustainable behaviours. ${ }^{57}$ Violations of social and human rights are at the centre of climate litigation, although the outcomes of disputes have been marginal with respect to the pressure that international movements against climate change and global warming have created with regard to environmental concerns. ${ }^{58}$ This is also linked to the perception that climate litigation is in its infancy and there is widespread scepticism on the part of the courts about entertaining any arguments sympathetic to the social effects of climate hazards. As Wilensky observed, 'climate change has been treated in the courts much like any other environmental issue and has not resulted

\footnotetext{
52 Brunetti et al. (2021).

53 Basel Committee on Banking Supervision (2021), pp 17-18.

54 Monnin (2018).

55 Eley (2021), p 9.

56 Chenet (2019), p 19.

57 Solana (2020), p 105.

58 Posner (2007), pp 9-10.
} 
in the development of a distinct climate-change jurisprudence'. ${ }^{59}$ However, there have been recent developments with regard to climate protection in the shape of successful lawsuits and unexpected judicial activism in the legal proceedings relating to environmental issues. This the case with the German Federal Constitutional Court, which declared partially unconstitutional the Federal Climate Change Act on the ground that it failed to indicate greenhouse gas (GHG) emission reduction targets, resulting in a breach of the country's binding commitment under the Paris Agreement. $^{60}$

A similar conclusion is found in the ruling in The Netherlands vs. Urgenda, where the Dutch Supreme Court held that a country's inadequate action on climate change may constitute a violation of human rights. ${ }^{61}$ The judges recognised the legally binding target and the deadline for the Dutch government to reduce GHG emissions, de facto imposing a duty to protect citizens' rights in the face of climate change. Most interestingly, the Hague District Court made an unprecedented order against Shell, ruling that the oil company needs to drastically reduce its carbon emissions and take robust steps towards sustainability. ${ }^{62}$ This decision is likely to create a precedent for other oil majors, which could face similar lawsuits and be required to change their business models. ${ }^{63}$ Despite the positive attitude of courts in the aforementioned cases, climate litigation is subject to hurdles when it comes to accessing available remedies for holding a company liable for poor sustainable standards. ${ }^{64}$

The harmful effects of climate litigation on companies' reputational capital and the value of assets can stimulate courts to rethink the existing legal arguments concerning corporate accountability for environmental damages and open up new judicial avenues for successful private lawsuits. The increase of successful cases in environmental litigation is remarkable and litigants seem less deterred by the thresholds required to initiate a climate claim which involve burdensome proofs, such as the causal nexus between the firm's behaviour in causing climate threats and the injury resulting from the harmful act. It is worth considering that the material risk for corporations can be the high costs of litigation and the reputational impact on markets arising from the public scrutiny, which can lead to a downgrade from rating agencies. ${ }^{65}$ Corporates need to manage climate risk because of their own economic futures, mandatory disclosure compliance and climate risk litigation. Automated information processing systems can support corporates to prevent and mitigate material risk on the basis of textual sources about environmental exposures.

\footnotetext{
59 Wilensky (2015), p 178.

60 See BVerfG (2021).

61 Case 19/00135 The State of the Netherlands (Ministry of Economic Affairs and Climate Policy) $v$. Stichting Urgenda, ECLI:NL:HR:2019:2007.

62 Case C/09/571932/ HA ZA 19-379 Milieudefensie et al. vs Royal Dutch Shell PLC, ECLI:NL: RBDHA:2021:5339.

63 Raval (2021).

64 For a discussion on tort law remedies in climate change litigation see Hunter and Salzman (2007), pp 1750-1751.

65 Ganguly (2018), pp 865-866.
} 


\section{The Use of Algorithmic Systems for Processing Granular Climate Information}

The application of AI systems for processing granular climate information has the potential to support companies with their mandatory reporting requirements and risk management. Achieving the full benefits of technology requires standardised access to corporations' operating systems and the data they contain. However, data management requirements for regulatory reporting present challenges such as poor data quality and poor data integration. An organisation's data management framework requires effective data governance, e.g., treatment of data as an asset, agreements between those who create data and those who use the data, and processes and controls of data collection. AI and machine learning offer a solution to fill the gaps of voluntary climate disclosures: they ensure measurable material risks and standardised auditing practices. This involves a risk management strategy which needs to adopt automated systems for extracting information about harmful events and engendering change in corporate behaviour. ${ }^{66}$

The opportunities provided by technology can be used in transformative ways which will yield far wider benefits than are sometimes envisaged. Valuation, while involving an inherent subjective element, can still be carried out using more standardised procedures; and the underlying data and risk factor simulations can be made available to external parties seeking to reach their own judgments on the valuation of assets and other exposures. Technological solutions can be deployed to improve the elaboration of annual company reports: they reduce the risk of bias and can assist in the analysis of 'structured' (reports) and 'unstructured' (statistical data) texts on climate. ${ }^{67}$ Specifically, NLP can classify the variety of metrics elaborated in the corporate reporting. The potential of cognitive technologies to improve the analysis of climate risk for firms is manifest: they extract information and translate it into knowledge in real time, which, at the same time, expedites data sharing. Basically, NLP techniques allow structured information to be extracted from natural language text. The structured information extracted by the NPL algorithm can potentially be used to populate a data model of a regulatory reporting system. NLP can also be used to uncover hidden patterns and anomalies in large quantities of text. AI tools can help make sense of unstructured texts, although much of the most relevant data held within a company and required for automation of operational tasks is structured but blocked. To unlock data, labelling or standardising it, corporations need to develop automated processing and intelligence. This also means there can be scale barriers: potentially only the largest companies are adequately placed to manage their data and take advantage of the technology opportunities. These challenges are even greater for sharing of data between firms because each firm has its own individual processes and definitions.

A valuable NLP application is ClimateBert (Bidirectional Encoder Representations from Transformers), an algorithm which elaborates textual data of companies'

66 Solomon et al. (2011), p 1119.

67 Antoncic (2020), pp 109-110. 
annual reports. ${ }^{68}$ It is a language representation software that excerpts specific wording from company disclosures into an accessible dataset in order to assess compliance with TCFD requirements. ${ }^{69}$ Risk management practices should enable automated processes for analysing large volumes of data to achieve real-time granular information. For climate reporting to be automated, data should be provided in a standardised format, but the fact that firms' data are stored in different systems requires allocating those data into a single standardised platform. Ensuring that the format used to standardise data can be reused across multiple climate reporting methods can create a potential downside to the efficiency of NLP applications. Regular changes to the format or maintaining several different formats for different regulatory reporting methods will significantly reduce the potential cost efficiencies of reports under algorithmic systems. Corporations should provide data in a number of different formats that are defined for each regulatory report while at the same time needing to ensure the data is correct before feeding it to automated processes.

\section{Conclusion}

To improve accuracy and clarity in climate risk reporting, corporations should engage with technological applications which can expedite the standardisation of data and the comparability of scores. Automation of climate risk assessment can reduce incentives for managerial opportunism and increase reliability of corporate sustainable management tools. The practical applications of technology can assist in accessing real-time granular data, leading to the improved disclosure of climaterelated financial risks and a better evaluation of climate impact. More specifically, the use of technology to better assess the climate risk requires greater standardisation of data, which will in turn enhance the transparency of firms' exposures and regulatory actions. The working of NLP methods can assist firms in improving their climate risk assessment process. Various cognitive computing systems have developed language representation models which enable companies to operationalise their instructions or responses to the climate regulatory requirements into compliance activities using NLP with machine learning techniques.

The deployment of technology holds out the promise of improving the assessment of climate risk and level of corporate exposures, and to enhance the transparency of monitoring processes. The main downside is the risk that the application of sophisticated machine-learning systems will exacerbate the possibility of technology malfunctioning and will fail to achieve its stated purposes. ${ }^{70}$ The potential benefits of technological innovation in climate change should be weighed carefully against the risks. In the long term, there is scope for AI to be used as a service provider for network interconnectedness and as a tool to monitor the ESG conduct of corporations.

\footnotetext{
68 Bingler et al. (2021), pp 2-3.

69 Devlin et al. (2019), p 4171.

70 Scherer (2016), p 359.
} 
Acknowledgements The author is grateful to the anonymous reviewer for the useful comments provided on an early draft. Any errors or omissions remain the sole responsibility of the author. I would like to dedicate this article to my dad, who gave me the strength to write during his illness.

Open Access This article is licensed under a Creative Commons Attribution 4.0 International License, which permits use, sharing, adaptation, distribution and reproduction in any medium or format, as long as you give appropriate credit to the original author(s) and the source, provide a link to the Creative Commons licence, and indicate if changes were made. The images or other third party material in this article are included in the article's Creative Commons licence, unless indicated otherwise in a credit line to the material. If material is not included in the article's Creative Commons licence and your intended use is not permitted by statutory regulation or exceeds the permitted use, you will need to obtain permission directly from the copyright holder. To view a copy of this licence, visit http://creativecommons.org/licen ses/by/4.0/.

\section{References}

Antoncic M (2020) Uncovering hidden signals for sustainable investing using Big Data: artificial intelligence, machine learning and natural language processing. J Risk Manag Financ Inst 13:106-113

Armour J, Parnham R, Sako M (2020) Augmented lawyering. ECGI Law Working Paper No. 558/2020. https://ssrn.com/abstract=3688896. Accessed 25 May 2021

Avgouleas E (2021) Resolving the sustainable finance conundrum: activist policies and financial technology. Law Contemp Probl 84:55-73

Balch O (2021) Big data helps put numbers on sustainability. Financial Times, 25 January 2021. https:// www.ft.com/content/2a405cf6-9592-4de2-960b-4c3e5d0df030. Accessed 25 May 2021

Basel Committee on Banking Supervision (2021) Climate-related financial risks-measurement methodologies. https://www.bis.org/bcbs/publ/d518.htm. Accessed 25 May 2021

Bingler JA, Kraus M, Leippold M (2021) Cheap talk and cherry-picking: what ClimateBert has to say on corporate climate risk disclosures. https://ssrn.com/abstract=3796152. Accessed 25 May 2021

Björkegren D, Blumenstock JE, Knight S (2020) Manipulation-proof machine learning. CEGA Working Paper Series No. 123. https://escholarship.org/uc/item/6tp4q9zv. Accessed 25 May 2021

Bresnahan K, Frankenreiter J, L'Helias S, Hinricks B, Hodzic N, Nyarko J, Pandya S, Talley EL (2021) Global investor-director survey on climate risk management. Columbia Law and Economics Working Paper No. 650. https://ssrn.com/abstract=3722958. Accessed 25 May 2021

Broeders D, Schlooz M (2021) Climate change uncertainty and central bank risk management. J Risk Manag Financ Inst 14:121-130

Brunetti et al. (2021) Climate change and financial stability. FEDS Notes. Board of Governors of the Federal Reserve System, Washington

Burton CD (2010) An inconvenient risk: climate change disclosure and the burden on corporations. Adm Law Rev 62:1287-1305

Busch D (2021) Sustainable finance disclosure in the EU financial sector. EBI Working Paper Series 2021-No. 70. https://ssrn.com/abstract=3650407. Accessed 25 May 2021

BVerfG (2021) Beschluss des Ersten Senats vom 24. März 2021. https://www.bundesverfassungsger icht.de/SharedDocs/Downloads/DE/2021/03/rs20210324_1bvr265618.pdf?_blob=publicationFile $\& v=1$. Accessed 25 May 2021

Carney M (2015) Breaking the tragedy of the horizon-climate change and financial stability. Speech given at Lloyd's of London. https:/www.bankofengland.co.uk/speech/2015/breaking-the-tragedyof-the-horizon-climate-change-and-financial-stability. Accessed 25 May 2021

Chenet H (2019) Climate change and financial risk. https://ssrn.com/abstract=3407940. Accessed 25 May 2021

Chiu I (2021) The EU sustainable finance agenda-developing governance for double materiality in sustainability metrics. European Business Organization Law Review, this volume

Chiu I, Lim E (2021) Technology vs ideology: how far will artificial intelligence and distributed ledger technology transform corporate governance and business? Berkeley Bus Law J 18:1-64 
Devlin J, Chang M-W, Lee K, Toutanova K (2019) BERT: pre-training of deep bidirectional transformers for language understanding. In: Proceedings of the 2019 Conference of the North American Chapter of the Association for Computational Linguistics: Human Language Technologies. https://doi.org/ $10.18653 / \mathrm{v} 1 / \mathrm{N} 19-1423$

Eley S (2021) Testing capacity of the EU banking sector to finance the transition to a sustainable economy. EBA Staff Paper Series No. 13. https://www.eba.europa.eu/sites/default/documents/files/ document_library/1010012/Testing\%20capacity\%20of\%20the $\% 20$ EU\%20banking\%20sector\% 20to\%20finance\%20the\%20transition\%20to\%20a\%20sustainable\%20economy.pdf. Accessed 25 May 2021

Enriques L, Zetzsche DA (2020) Corporate technologies and the tech nirvana fallacy. Hastings Law J 72:55-98

European Commission (2018) Action plan: financing sustainable growth. COM (2018) 97 final

European Commission (2019) Guidelines on reporting climate-related information. https://ec.europa.eu/ finance/docs/policy/190618-climate-related-information-reporting-guidelines_en.pdf. Accessed 25 May 2021

European Commission (2020) Study on directors' duties and sustainable corporate governance. https:// op.europa.eu/en/publication-detail/-/publication/e47928a2-d20b-11ea-adf7-01aa75ed71a1/langu age-en. Accessed 25 May 2021

FCA (2020) Proposals to enhance climate-related disclosures by listed issuers and clarification of existing disclosure obligations. Policy Statement PS20/17. https://www.fca.org.uk/publication/policy/ps2017.pdf. Accessed 25 May 2021

FCA (2021) Climate-related reporting requirements. https://www.fca.org.uk/firms/climate-change-susta inable-finance/reporting-requirements\#international. Accessed 14 May 2021

Ferrarini G (2020) Corporate purpose and sustainability. ECGI Working Paper 559/2020. http://ssrn.com/ abstract_id=3753594. Accessed 25 May 2021

Ferrarini G, Siri M, Zhu S (2021) The EU sustainable governance consultation and the missing link to soft law. ECGI Law Working Paper No. 576/2021. https://ssrn.com/abstract=3823186. Accessed 25 May 2021

Financial Reporting Council (2020) Climate thematic. https://www.frc.org.uk/getattachment/ab63c2206e2b-47e6-924e-8f369512e0a6/Summary-FINAL.pdf. Accessed 25 May 2021

Financial Stability Board (2016) Recommendations of the Task Force on Climate-related Financial Disclosures. https://www.fsb.org/wp-content/uploads/Recommendations-of-the-Task-Force-on-Clima te-related-Financial-Disclosures.pdf. Accessed 25 May 2021

Financial Stability Board (2020) Task Force on Climate-related Financial Disclosures. 2020 Status Report. https://assets.bbhub.io/company/sites/60/2020/09/2020-TCFD_Status-Report.pdf. Accessed 25 May 2021

Gal MS, Rubinfeld DL (2019) Data standardization. NYU Law Rev 94:737-770

Ganguly G (2018) If at first you don't succeed: suing corporations for climate change. Oxf J Leg Stud 38:841-868. https://doi.org/10.1093/ojls/gqy029

Gensler G, Bailey L (2020) Deep learning and financial stability. Working Paper. https://ssrn.com/abstr act $=3723132$. Accessed 25 May 2021

Gortsos C (2020) The Taxonomy Regulation: more important than just as an element of the capital markets union. European Banking Institute Working Paper Series 2020 No. 80. https://ssrn.com/abstr act $=3750039$. Accessed 25 May 2021

Gotthardt M, Koivulaakso D, Paksoy O, Saramo C, Martikainen M, Lehner O (2020) Current state and challenges in the implementation of robotic process automation and artificial intelligence in accounting and auditing. ACRN Oxford J Finance Risk Perspect 9:90-102

Hain LI, Kölbel JF, Leippold M (2021) Let's get physical: comparing metrics of physical climate risk. https://ssrn.com/abstract=3829831. Accessed 25 May 2021

HM Treasury (2019) Green finance strategy. https://www.gov.uk/government/publications/green-financestrategy. Accessed 25 May 2021

HM Treasury (2020) Interim Report of the UK's Joint Government-Regulator TCFD Taskforce. https:// assets.publishing.service.gov.uk/government/uploads/system/uploads/attachment_data/file/933782/ FINAL_TCFD_REPORT.pdf. Accessed 25 May 2021

Hunter D, Salzman J (2007) Negligence in the air: the duty of care in climate change litigation. Univ Pa Law Rev 155:1741-1794 
Inderst G, Kaminker C, Stewart F (2012) Defining and measuring green investments: implications for institutional investors' asset allocations. OECD Working Papers on Finance, Insurance and Private Pensions No. 24. https://doi.org/10.1787/5k9312twnn44-en

Ioannou I, Serafeim G (2019) The consequences of mandatory corporate sustainability reporting. In: McWilliams A et al. (eds) The Oxford handbook of corporate social responsibility: psychological and organizational perspectives. OUP, Oxford

Johnson K, Pasquale F, Chapman J (2019) Artificial intelligence, machine learning, and bias in finance: toward responsible innovation. Fordham Law Rev 88:499-530

Johnston A (2018) Climate-related financial disclosures: what next for environmental sustainability? University of Oslo Faculty of Law Legal Studies Research Paper Series No. 2018-02. https://ssrn.com/ abstract $=3122259$. Accessed 25 May 2021

Lewis C, Young S (2019) Fad or future? Automated analysis of financial text and its implications for corporate reporting. Account Bus Res 49:587-615

Luccioni A, Palacios H (2019) Using natural language processing to analyze financial climate disclosures. https://www.climatechange.ai/papers/icml2019/34/paper.pdf. Accessed 25 May 2021

Lui A, Lamb GW (2018) Artificial intelligence and augmented intelligence collaboration: regaining trust and confidence in the financial sector. Inf Commun Technol Law 27:267-283

Lund DS, Pollman E (2021) The corporate governance machine. ECGI Law Working Paper No. 564/2021. https://ssrn.com/abstract=3775846. Accessed 25 May 2021

Lusk G (2021) Looking forward and backward at extreme event attribution in climate policy. Ethics Policy Environ 24:1-15. https://doi.org/10.1080/21550085.2020.1848195

Macchiavello E, Siri M (2021) Sustainable finance and Fintech: can technology contribute to achieving environmental goals? A preliminary assessment of 'Green FinTech'. EBI Working Paper Series 2020-No. 71. https://ssrn.com/abstract=3672989. Accessed 25 May 2021

Monnin P (2018) Integrating climate risks into credit risk assessment. CEP Discussion Note 2018/4. https://ssrn.com/abstract=3350918. Accessed 25 May 2021

Möslein F, Engsig Sørensen K (2021) Sustainable corporate governance: a way forward. ECGI Law Working Paper No. 583/2021. http://ssrn.com/abstract_id=3761711. Accessed 25 May 2021

Posner EA (2007) Climate change and international human rights litigation: a critical appraisal. CoaseSandor Institute for Law \& Economics Working Paper No. 329. http://ssrn.com/abstract_id= 959748. Accessed 25 May 2021

Raval A (2021) Dutch court orders Shell to accelerate emissions cuts. Financial Times, 26 May 2021. https://www.ft.com/content/340501e2-e0cd-4ea5-b388-9af0d9a74ce2?emailId=60ae5ebe4ab8400 0040e79d7\&segmentId=3d08be62-315f-7330-5bbd-af33dc531acb. Accessed 26 May 2021

Ryan-Collins J (2019) Beyond voluntary disclosure: why a 'market-shaping' approach to financial regulation is needed to meet the challenge of climate change. SUERF Policy Note Issue No 61. https:// www.suerf.org/docx/f_a821a161aa4214f5ff5b8ca372960ebb_4805_suerf.pdf. Accessed 27 May 2021

Scherer MU (2016) Regulating artificial intelligence systems: risks, challenges, competencies, and strategies. Harvard J Law Technol 29:354-398

Schoenefeld JJ, Hildén M, Jordan AJ (2018) The challenges of monitoring national climate policy: learning lessons from the EU. Clim Policy 18:118-128

Solana J (2020) Climate litigation in financial markets: a typology. Transnatl Environ Law 9:103-135. https://doi.org/10.1017/S2047102519000244

Solomon JF, Solomon A, Norton SD, Joseph NL (2011) Private climate change reporting: an emerging discourse of risk and opportunity? Account Auditing Account J 24:1119-1148. https://doi.org/10. $1108 / 09513571111184788$

Stein AL (2020) Artificial intelligence and climate change. Yale J Regul 37:890-939

Sustainability Accounting Standards Board (2021) Climate risk. Technical Bulletin. https://www.sasb. org/knowledge-hub/climate-risk-technical-bulletin/. Accessed 25 May 2021

UK Department for Business, Energy \& Industrial Strategy (2021) Consultation on requiring mandatory climate-related financial disclosures by publicly quoted companies, large private companies and Limited Liability Partnerships (LLPs). https://www.gov.uk/government/consultations/manda tory-climate-related-financial-disclosures-by-publicly-quoted-companies-large-private-companiesand-1lps. Accessed 25 May 2021

United Nations Framework Convention on Climate Change (2015) The Paris Agreement. https://unfccc. int/process-and-meetings/the-paris-agreement/the-paris-agreement. Accessed 25 May 2021 
Wilensky M (2015) Climate change in the courts: an assessment of non-U.S. climate litigation. Duke Environ Law Policy Forum 26:131-179

Yeung K (2019) Why worry about decision-making by machine? In: Yeung K, Lodge M (eds) Algorithmic regulation. OUP, Oxford

Zenghelis D, Stern N (2016) The importance of looking forward to manage risks: submission to the Task Force on Climate-related Financial Disclosures. Policy paper. The London School of Economics and Political Science, Grantham Research Institute on Climate Change and the Environment, London. http://eprints.1se.ac.uk/67133/1/Zenghelis-and-Stern-policy-paper-June-2016.pdf. Accessed 25 May 2021

Publisher's Note Springer Nature remains neutral with regard to jurisdictional claims in published maps and institutional affiliations. 